\title{
CONSTANTIJN HUYGENS' PATHODIA SACRA ET PROFANA. A SENTIMENTAL JOURNEY
}

\author{
GANDOLFO CASCIO \\ UTRECHT UNIVERSITY
}

\begin{abstract}
Constantijn Huygens (1596-1687) in 1620 traveled to Venice as a secretary of ambassador Van Aerssen: he was the only member of the legation who knew Italian. This visit to the Most Serene Republic has been extremely important to him, since he could experience the many natural and artistic wonders he had a mere abstract knowledge of. However, in his life the Dutch poet made a more interesting journey: an intellectual and sentimental one, writing his Pathodia sacra et profana. In this collection we have compositions written in Italian in the very fashionable style of Petrarch. In my essay, I will try to make an historic-philological analysis of this opus in order to establish how the original paradigm has been respected or violated, both in style as well as content.
\end{abstract}

$$
\text { Key Words }
$$

Constantijn Huygens, Reception theory, stylistics, Petrarchism, Baroque.

$$
\begin{aligned}
& \text { to flee time you need to seek refuge before time, } \\
& \text { solely in its length. } \\
& \text { Carlo Levi }{ }^{1}
\end{aligned}
$$

In 1891, more or less midway upon the journey of his life, Paul Gaugain left his country and set sail on a ship that anchored in the port of Papeete. A couple of years later, Amedeo Modigliani used to portray his friends à la Giorgione. These

1 'Per fuggire il tempo bisogna rifugiarsi prima del tempo, nella pura durata': Carlo Levi, comment on Sterne's Sentimental Journey Through France and Italy (1768), in Carlo Levi, Prima e dopo le parole. Scritti e discorsi sulla letteratura, Rome: Donzelli, 2001, p. 154. 
choices prove a shared existential discomfort that caused a radical rejection of their spatiotemporal coordinates. Thus, the two bohémiennes in order to survive a Zeitgeist impregnated with an unbearable Baudelairian Spleen, fled somewhere else. One settled in an exotic physical space; the other, more sophisticatedly, renounced an ordinary life and took shelter in the magnificent legacy of his homeland.

What has this preamble to do with Constantijn Huygens? A lot, since it functions as a counter-figural interpretation that resembles the experience of the baroque poet. The implicit idea that supports this comparison, is that even a literary journey can be considered in the same way as a literal escape.

To demonstrate this thesis, my essay focuses on textual evidence; however, such proof will be linked to some contextual data (historical and biographical) as well.

The Dutch poet Constantijn Huygens wished to leave behind his life in the Republic and try to find a different hortus that would be consistent with his Weltanschauung. Let's not forget that his fellow countrymen were engaged and employed in an exhausting conflict: the Eighty Years' War, in other words the Dutch revolt to obtain independence from the Spanish crown (1568-1648); on top of this crisis, the country was offended by the quarrels between religious sects. ${ }^{2}$ Also Huygens' friend Barlaeus was involved in the religious-political row, since he was seen as an extremist, and was purged by the ruling power, embodied by the Stadtholder Maurits, a system based on conflicts of interests.

Constantijn Huygens was a well-established man of letters, ${ }^{3}$ connected with the fabric of the élite. With his father's recommendation, who was secretary of the Council of State, and by virtue of his language skills, he joined the diplomatic legation as a secretary of the ambassador of the Seven United Provinces, François van Aerssen. Scope of the mission was to seek support by the all-powerful Lagoon city and ratify a treaty of alliance against the Spaniards.

They reached the Serenissima in June 1620, almost at the end of the so called Twelve Years' Truce, following the German-Swiss route: Cologne, Heidelberg and Tubingen, paying visit to some protestant leaders. In the northern part of the Peninsula, he admired the lakes, Verona and Vicenza, where he was amazed at the natural display of grandeur of the Alps and dismayed by the man-crafted Palladian sites.

He staid three weeks and, besides complying with his official duties, he enjoyed the sophisticated cultural activities. We know for a fact that he took the

Remonstrants vs. Gomarists, also called Counter-Remonstrans.

3 His works have been collected in this edition which also serves als my reference point: Oeuvres complètes de Christiaan Huygens publiées par la Société Hollandaise des Sciènces, 22 vols, La Haye: Martinus Nijhoff, 1888-1950. 
chance to visit the Sansovinian library, and attended one of Claudio Monteverdi's mise-en-scène. Especially this musical encounter will be of pivotal importance. ${ }^{4}$ However, in spite of these appearances, we cannot categorize Huygens visit to Italy as a Grand Tour, because it does not fulfil two important criteria: 1 . he did not go to Italy to refine his education; 2 . his stay was too short.

He reported the details of his journey in a diary written in French. The manuscript circulated among friends and connoisseurs. These notes, which only recently have been published, inform us about something rather useful for my quest. I refer to one of the official meetings when Antonio Priuli ${ }^{5}$ complimented the Dutch clerk on his knowledge of Italian. ${ }^{6}$

Now, what interests me, is to verify that the reported doge's comment was not just an act of institutional courtesy, or a dear memory blown out of proportion by Huygens' unrestrained self-esteem. Verily, his knowledge is confirmed by external sources which inform us that he had reached such a level that he loves to take an amusing remark or a pithy saying and reformulate it in verse in three or four different languages with up to six different versions'?

What about his enterprise to acquire Italian? What we do know is that he started to learn it sometime before his journey to Venice. Most probably he took lessons before February 1615. We are certain of this, thanks to his diary, where he noted down:

'In Italiacae ling. Rudimentis cum BIONDI, et LIERE DEPUIS. Diu intellexeram linguam'.

Further, it is recorded that the exclamation 'Basta, Basta' ('Enough, enough!') have been his first Italian written words ${ }^{9}$, and that he used them in relation to his friend Contarini, with whom he remained engaged in an exchange of letters. Choosing to apply himself in practising yet another language, Huygens did not allow himself a luxury, neither we must considered it as an extravagant affectation.

4 See Rudolf, Rasch "Italia decolour"? Constantijn Huygens and Italian Music', in Dinko Fabris, Margaret Murata (eds.), 'Passaggio in Italia': Music on the Grand Tour in the Seventeenth Century, Turnhout: Brepols, 2015, pp. 85-108.

5 Doge of the Serenissima between 17 May 1618 and 12 August 1623.

6 See Constantijn Huygens, Journaal van de reis naar Venetië, red. F.R.E. Blom, Amsterdam: Prometheus - Bert Bakker, 2003, pp. 103-105.

7 Leonard Forster, The Poets Tongues. Multilingualism in Literature, Cambridge: Cambridge University Press, 1970, p. 42.

8 Huygens 1884/5: 9, quoted in Christopher Joby, The multilingualism of Constantijn Huygens (1596-1687), Amsterdam University Press, 2014, p. 69.

9 Ibid., p. 70. 
Italian was spoken by the community of intellectuals, by the travelling merchants and the diplomats. The publication of books in the original versions was large and, since 2 March 1668, the printing and circulation of a periodical, the Gazzetta di Amsterdam, was a fact. ${ }^{10}$

Well educated people red Italian literature, and I do not mean exclusively the classics, with Petrarch on the top-list, but some more recent best sellers as well, such as Castiglione's, Machiavelli's; or even contemporary writers like Giambattista Marino and some more extravagant ones too.

To strengthen my statement, I report a quote from Huygens' autobiography, ${ }^{11}$ published in 1677 when the writer was still alive, and in here he mentions Traiano Boccalini's work defining it as 'a modern author with an extremely careful and pure style'. ${ }^{12}$ This entry is evidently more than a document of his literary up-to-dateness, it provides us a concrete information about his knowledge, because Huygens' appreciation, as we read the whole comment, seems based not on a perception, or an opinion pulled together by hearsay evidence: no, it is a clear and well supported stylistic judgment. This is important to me to establish with certainty Huygens' competence of the foreign language even dealing with the tricky business of humour and humourism. Having said all this on the historical context and the personal circumstances, I wish now to define more accurately the text itself.

In the course of his long life (Huygens was born in The Hague in 1596 where he also died in 1687) he wrote poems in Latin, French and Italian as well. In the latter he probably wrote one poem few years before he began to attend to the Pathodia. He must have done this as apprenticeship in writing a lyrical matter in the newly learned language.

In total "We have 219 lines of verse that Huygens wrote in Italian. Whilst a small number of these appear in multilingual poems, most of them are in poems written entirely in Italian'; ${ }^{13}$ but let us proceed in an orderly manner in the description of such development.

In 1640 he sent a French and an Italian text to his friend Gaspar Duarte; post 1642 he wrote the poem Già ti chiesi un sospir; and then we are informed about a composition entitled Giunse fiamma sottil (So arrived a thin flame) which, how ironic this title can now be considered (!), got destroyed during a fire in the Amsterdam New Church on 11 January 1645. It is Huygens himself who recorded the accident: 'In incendium Templi Novi Amstelod. ex Italico meo, cujus est

10 See Vincenzo Lo Cascio, L'italiano nel secolo d'oro olandese, in Harro Stammerjohann (ed.), Italiano: lingua di cultura europea, Atti del simposio internazionale in memoria di Gianfranco Folena, Weimar, 11-13 aprile 1996, Tübingen: Narr, 1997, p. 248.

11 De vita propria sermonum, inter liberos libri II, 1677.

12 Constantijn Huygens, Mijn jeugd, ed. C.L. Heesakkers, Hilversum: Griffioen, 1987, p 87.

13 Christopher Joby, The multilingualism of Constantijn Huygens (1596-1687), op. cit., p. 94. 
initium, Giunse fiamma sottil' ${ }^{14}$ After this very first exercise, he wrote the Pathodia sacra et profana. The book is apparently anonymous, since the poet uses the pseudonym of Occupati. I shall return to this term later.

It contains 39 texts divided in two parts: the sacred one, contains 20 pieces which are quotations from the Psalms in Latin; the secular part is composed of a first session of 12 Italian madrigals and then a second of 7 French airs de cour. Two of the Italian texts, \# 22 and 28, will afterwards be translated by Huygens in French; while, in 1639, \# 24, Quel neo quel vago neo, will be imitated by Huygens himself and become his famous poem Die mael die soete mael. I do care to specify that of the Italian poems, more than half are taken by Giambattista Marino's Rime and have been adapted - this is evident in the title - probably for singing and prosody reasons. For example, Se la doglia e'l martire becomes in the Pathodia Morte dolce etc.

This is the account of the source and the target texts:

\begin{tabular}{|r|l|l|}
\hline & Pathodia sacra & Psalm \\
\hline 1 & Multi dicunt animae meae & $3,3-4$ \\
\hline 2 & Domine ne in furore tuo & $6,2-4$ \\
\hline 3 & Usquequo Domine & $12 / 13,1-4$ \\
\hline 4 & Domine Deus meus & $29 / 30,3-5$ \\
\hline 5 & Avertisi faciem & $29 / 30,8-10$ \\
\hline 6 & Dilataverunt super me & $34-35,21-22$ \\
\hline 7 & Ab omnibus iniquitatibus & $38-39,9-11$ \\
\hline 8 & Sitivit anima mea & $41-42,3$ \\
\hline 9 & Quare tristis es & $41-42,6-7$ \\
\hline 10 & Iniquitatem meam ego cognovi & $50-51,5-6$ \\
\hline 11 & Domine spes mea & $70-71,5,9,22$ \\
\hline 12 & In quo corriget & $118-119,9-10$ \\
\hline 13 & Cognovi Domine & $118-119,25-26$ \\
\hline 14 & Quomodo dilexi & $118-119,97,102-103$ \\
\hline
\end{tabular}

14 Constantijn Huygens, Gedichten. Deel 4: 1644-1652, ed. J.A. Worp, Groningen: J.B. Wolters, 1894 , p. 24. 
Gandolfo Cascio

\begin{tabular}{|r|l|l|}
\hline 15 & Erravi & $118-119,176$ \\
\hline 16 & Laetatus sum & $121-122,1-3$ \\
\hline 17 & De profundis clamavi & $129-130,1-3,5$ \\
\hline 18 & Confitebor tibi Domine & $137-138,1-2$ \\
\hline 19 & Proba me Deus & $138-139,23-24$ \\
\hline 20 & Memor fui dierum antiquorum & $142-143,5-7$ \\
\hline
\end{tabular}

\begin{tabular}{|c|c|c|c|}
\hline & Pathodia profana A (Italian) & Author & \begin{tabular}{|l} 
Original \\
title
\end{tabular} \\
\hline 21 & Se la doglia e'l martire & Marino & $\begin{array}{l}\text { Morte } \\
\text { dolce }\end{array}$ \\
\hline 22 & Sospir che del bel petto & Marino & \begin{tabular}{|l|} 
Sospiro \\
della sua \\
Donna \\
\end{tabular} \\
\hline 23 & Temer Donna non dei & Marino & \begin{tabular}{|l|} 
Amor \\
secreto
\end{tabular} \\
\hline 24 & Quel neo quel vago neo & Marino & $\begin{array}{l}\text { Neo di bel } \\
\text { volto }\end{array}$ \\
\hline 25 & O chiome erranti & Marino & \begin{tabular}{|l} 
Errori di \\
bella \\
chioma
\end{tabular} \\
\hline 26 & Orsa bella e crudele & Marino & \begin{tabular}{|l|} 
Caccia \\
amorosa
\end{tabular} \\
\hline 27 & Con la candida man & Huygens & \\
\hline 28 & Già ti chiesi un sospir & Huygens & \\
\hline 29 & A dispetto de' venti & Huygens & \\
\hline 30 & Che rumore sento fuore & Huygens & \begin{tabular}{|l|} 
Riposta \\
dalla \\
finestra
\end{tabular} \\
\hline 31 & Deh, s'a tanto beltà & Marino \& Huygens & \\
\hline 32 & Va donna ingrata & Huygens & \\
\hline & \multicolumn{3}{|l|}{ Pathodia profana B (French) } \\
\hline 33 & \multicolumn{3}{|l|}{ Que ferons-nous } \\
\hline 34 & \multicolumn{3}{|l|}{ Graves tesmoins de mes délices } \\
\hline
\end{tabular}


Constantijn Huygens' Pathodia sacra et profana: A Sentimental Journey

\begin{tabular}{|c|l|}
\hline 35 & Vous me l'aviez bien dit \\
\hline 36 & Quoy Clorinde tu pars \\
\hline 37 & Tu te trompes Philis \\
\hline 38 & Aubade: J'ai veu le point du jour \\
\hline 39 & Sérénade: Ne crains point le serein \\
\hline
\end{tabular}

The songs can be placed in Monteverdi's and Caccini's tradition of the Seconda pratica which promoted more freedom from the rigorous style of, for instance, Palestrina's Prima pratica. It is, as Vincent Duckles describes it, 'one of the most interesting collections of continuo song published north of the Alps during the $17^{\text {th }}$ century'. ${ }^{15}$ The adopted linguistic strategy, unusual but not infrequent, can be seen as part of heteroglossy, to use a terminology that I gladly borrow from the well-known study of Gianfranco Folena. ${ }^{16}$ All of them were supposed to be performed vocally and with theorbo and basso continuo accompaniment (though the original project intended to use the lute which, in the meantime got out of fashion); the ones in Italian and French are, as I already mentioned, arias.

The title represents a pure example of ingenuity, since this is a neologism that combines the words pathos and odè. This is not a unique episode. We know from Huygens' correspondence that he 'invented a number of Greek words. ${ }^{17}$

On the frontispiece the author is missing. His name is replaced by the alias Occupati (The busy man) as we can see in the editio princeps. This choice is peculiar, to say the least because it is in contrast to the content and themes of the book, since both genres in the Pathodia - religious psalms and amorous songs would recommend a disposition towards the otium, while here the authors negotium is stressed.

This could be explained as an act of self-fashioning where Huygens is giving to his readers a portrait of a man whose longing to such a state was in contrast to his daily hectic life. It is a defensible hypothesis when we think that in 1625 he had published a collection of poems called Ledige Uren, and that is Otia.

15 Duckles Vincent, 'Review to Frits Noske, Pathodia sacra et profana by Constantijn Huygens', Journal of the American Musicological Society, 14:1 (Spring 1961), p. 82.

16 Gianfranco Folena, L'italiano in Europa. Esperienze linguistiche del Settecento, Turin: Einaudi, 1983.

17 Christopher Joby, 'The Use of Greek in the Correspondence of Constantijn Huygens (1596-1687)', Humanistica Lovaniensia 61 (2012), p. 345. 
I'd also like to point out that such a representation can also be considered from a socioreligious perspective, when we are reminded of the different views within Western Christians with regard to the doctrine of the Justification: in short the irresolute cultural conflict between the industrious Catholics (who rely on free will and let cooperate faith and action) and the contemplative Protestants (whose salvation depends solely in God's will).

Anyhow, a busy man Huygens most certainly was, and so - amongst lots of paperwork and with a close eye to the globe - he was portrayed by Thomas de Keyser (fig. 1). To improve the circulation of the Pathodia, for instance, he engaged himself in an advertising campaign, sending some of the poems to his friends Mersenne and Gobert, influential members of the cultural circles. The latter seems impressed and demonstrates his appreciation. ${ }^{18}$

It is dedicated to Utricia Ogle, whom is called, as muse to the poet, nostra Siren; she is a niece of an English diplomat with whom Huygens had an intellectual relation. We have a charming picture of her by the hand of Jan de Bisschop, courteously named Lady Swann.

The princeps was eventually published in Paris by Pierre Ballard in December 1647: apparently 'the Seven Provinces, so very famous for their publishing houses, did not have the chance to print it'. ${ }^{19}$

After the Psalms, Huygens put a long dedication, where he, using the rhetoric of a captatio benevolentiae, he excuses himself and presents a whole repertoire of classical writers. This choice is of course more than name-dropping. It could be interpreted as an attempt to demonstrates that 'the author does not want to be seen as an "ordinary" composer. He is a literate and takes every chance to show it'. ${ }^{20}$

After concluding his task, he must have felt rather pleased with the results of his effort, so much that he was quite confident since he wished to send his libretto to the marquise Cimenes, to whom he wrote on 21 October 1647, apologising for the late sending:

'As a consequence of my Parisian printer's tardiness, I am not yet able to answer your lordship by sending my Pathodia, but I hope to be able to do so within a few days'. $^{21}$

18 See Constantijn Huygens, Letter \# 4547, in Constantijn Huygens, Briefwisseling. Deel 4: 1644-1649, ed. J. A. Worp, La Haye: Martinus Nijhoff, 1915, p. 390.

19 Jacop A. Worp, ivi, p. XIV.

20 Astrid De Jager, 'Constantijn Huygens' Passion: Some Thoughts About the Pathodia Sacra Et Profana', Tijdschrift Van De Koninklijke Vereniging Voor Nederlandse Muziekgeschiedenis, 57:1 (2007), p. 29.

21 Letter \# 4692, in Constantijn Huygens, Briefwisseling. Deel 4: 1644-1649, op. cit., p. 434. 
This is, more or less, the biography of the text. Now, I will deal with the main questions inherent to my essay: why did Huygens wrote these songs in Italian? The reason, in my opinion, is mainly stylistic, or better said, it is a stylistic norm that he cared to comply with. In order to make my point clear, I need to take a step backwards. In classical and late medieval rhetoric precepts - more specifically I refer to Aristotle' Rhetoric as well as Poetics; Cassiodorus in the proem of his Variae epistolae; Horace's Epistula ad Pisones (commonly known as Ars Poetica); Quintilian in the Institutio oratoria; and, in the early modern age, Dante's De vulgari eloquentia - the subject of the poem defines, regulates and standardizes the register that must be used amongst the three available varieties: humilis, mediocris or sublimis.

In Italy and also outside, these norms, established in the treatises, were very much still in use in the XVII century, or, I'd better say, they were brought back to life and in a vigorous manner too, since also Aristotelianism itself got back being the mainstream philosophy. To this theoretical phenomenon, which is, of course, more than an intellectual repechage, an addition was made, a corollary to the theorem, if you wish, which is not of no importance: the choice of the language would be subordinated to the theme of the poem. Practically this means that, when speaking of love it is this very topic that requires to be said in Italian. The reason is intrinsic to the subject and has to do with aesthetics as well as with literary prestige. It seems then that the amorous matters would bear no other tongue but solely Italian: 'Questa è la lingua di cui si vanta amore' [This is the tongue of which Love is most proud], just to use Milton's verse, who is not just Huygens' contemporary, but one who shared the experience to write poetry in Italian. ${ }^{22}$ In his case 5 sonnets. Now, because I am involving the English poet, surely it will be useful to state precisely that:

'For Milton, as for Huygens, and the men of their time, there is no mystique about languages; they are simply different media in which a poet can work - and can be expected to work. ${ }^{23}$

This practice of writing about love - of course, in a sublime style ${ }^{24}$ and according to the Petrarchesche manner - was initiated in the Renaissance, when it even became a custom, and persisted very well in the Baroque period.

22 Quoted and illustrated in Gordon Teskey, The Poetry of John Milton, Cambridge: Harvard University Press, 2015, p. 30. Very interesting on this subject is also Furio Brugnolo, La lingua di cui si vanta Amore. Scrittori stranieri in lingua italiana dal Medioevo al Novecento, Rome: Carocci, 2009.

23 Leonard Forster, The Poets Tongues. Multilingualism in Literature, op. cit. p. 47. 
Another proof to this statement is given, a contrario, by the simple fact that the Psalms had not been translated in neither of the two Romance languages used for the other compositions. More of a contextual evidence can be produced by another protagonist of the Dutch Baroque culture, namely the painter Frans Hals. If we look at one of his masterpieces, Marriage Portrait of Isaac Massa and Beatrix van der Laen (fig. 2), we can see the man, a grain trader and diplomat during the envoy to Moscow (a similitude to Huygens' biography) who firmly keeps the right hand on his heart; his young spouse has rosy cheeks. There are signs of their mutual love. Moreover, the couple is at ease, and is casually placed in front of a Giardino all'italiana where stylistically symmetry and human order are the décor of an exquisite example of the Garden of love. The atmosphere, including the elegantly walking couple and the classical statues, resembles Italy and the Italian courtly love: an artifice as effective as illusive, I must say.

As a contrast, let us look at another family portrait of Hals, one in a further stadium of life, where, apparently love has been substituted by children who cannot stand still, a desolate polder landscape, and no eye-contact between husband and wife (fig. 3).

Just as in the first of Hal's pieces, also Huygens madrigals attempt to recreate the same charming and exotic setting: the only difference is in the tools: where images are replaced by language. The strength of such a connection is based upon the authority of the Horatian maxim 'Ut pictura poësis' ${ }^{25}$ [As is painting so is poetry]. From this sentence, I deduce that, if, for the spectator, the results of the Sister Arts are equal, so it must be for the means and tools used by the two creators.

Even though the Pathodia is a great homage to Marino, ${ }^{26}$ especially in the pathetic pose, as the title suggests, Petrarch is really the main source and Huygens work can easily be seen as part of the very common and Paneuropean practice of Petrarchism. ${ }^{27}$

Huygens' Italy was primarily - it couldn't possibly be otherwise - Petrarch's Italy, ${ }^{28}$ to such an extent that Pieters, most justly defines it, an 'enchantment'. ${ }^{29}$

24 When I use the adjective 'sublime', I am referring to the classical the distinction of the genera dicendi; see Giuseppe Panella, Storia del Sublime. Dallo Pseudo Longino alle poetiche della Modernità, Florence: Clinamen, 2012.

25 Horace, Ars Poetica, 361-362.

26 See Pieter E.L. Verkuyl, 'Is Huygens een marinist?', De Nieuwe Taalgids 56 (1963), pp. 129-140, 193-205.

27 On the European Petrarchism, see Gian Mario Anselmi, Keir Elam, Giorgio Forni, Davide Monda (eds.), Lirici europei del Cinquecento. Ripensando la poesia del Petrarca, Milan: BUR, 2004.

28 On Huygens's indebtedness to Petrarchist conventions, see Ton van Strien in Constantijn Huygens, Korenbloemen, ed. T. van Strien, Amsterdam: Querido, 1996, p. 77. 
As a matter of fact, his attempt to look like the Aretine went further than imitatin him. As Ypes informs us, he quoted his work a lot in his own poems and letters and he "could understand the crucial aspects of the Canzoniere and those of the poet even better than Hooft'. ${ }^{30}$

To further understand the role of Petrarca, I'll give one more example. This is Huygen's Con la candida man ardita (\# 27):

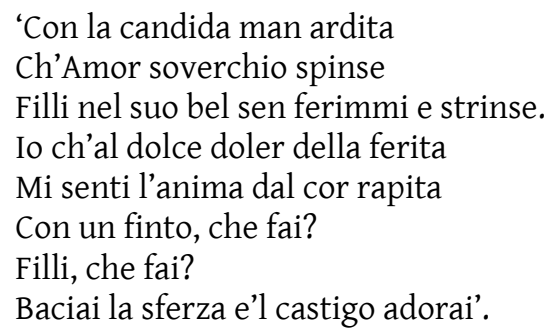

After reading this passage, we experience how the Dutch writer's idea of love exploits the amorous norms borrowed by the dominant literary vogue of his age. To be more precise: 1 . the fabula and the lexicon are Petrarchan: 'ferir me de saetta in quello stato, a voi armata non mostrar pur l'arco (RVF III 13-14); 2. the linguistic register is high; 3. there is an accommodating use of voluptas dolendi ('dolce doler della ferita', 'castigo adorai'); 4. Neoplatonism holds up the argumentation of the poem ('Mi senti l'anima dal cor rapita'). This intertextual evidence shows that Huygens' succeeded to master Petrarca's lyrical precepts. However, this is not a mere example of $\mu$ í $\eta$ or $\zeta$ but, I venture to suggest that it is a case of literary cannibalism: an experience, somehow, shared with Francesca Da Rimini, Don Quijote and Emma Bovary. ${ }^{31}$ I mean to say that Huygens did not just intend to 'copy' or emulate his model, but he attempted to materialize his baroque dream: to be the living word on the the great theatre of the world. ${ }^{32}$

To conclude: in this assignment, I have addressed some significant issues which show how Huygens' Pathodia can be assimilitated to the theoretical concept of a journey. The evidence presented has shown that to reach his

29 See Jürgen Pieters, Op zoek naar Huygens. Italiaanse leesnotities, Gent: Koninklijke Academie voor Taal- en Letterkunde, Poëziecentrum, 2014.

30 Catharina Ypes, Petrarca in de Nederlandse letterkunde, Amsterdam: De Spieghel, 1934, p. 97.

31 For further investigations on literary cannibalism, I refer the reader to my chapter entitled “"Non è Francesca": la letteratura come imitazione' in Gandolfo Cascio, Un'idea di letteratura nella 'Commedia', Rome: Società Editrice Dante Alighieri, 2015, pp. 49-66, particularly p. 64-65.

32 I refer to Pedro Calderón de La Barca's El gran teatro del mundo (1633-1636). 
utopia $^{33}$ he had not to pack, sail or ride through continental Europe and cross the Alps; for him sufficed to explore a literary and linguistic place. He only had to pick his copy of the Canzoniere from a shelf.

In this act Huygens confirms his modernity, and the passage to a new era, made more of books and phantasies than reality and experiences, because, as Walter Benjamin suggests 'the Renaissance explores the universe; the Baroque explores libraries'. ${ }^{34}$

\section{Illustrations}

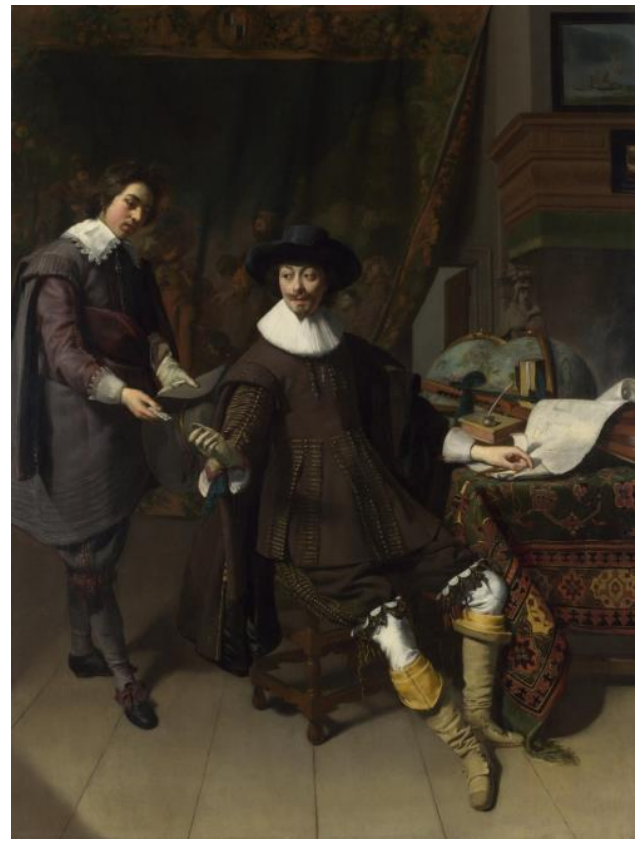

Fig. 1: Thomas de Keyser, Portrait of Constantijn Huygens and his Clerk (?), 1627, London, National Gallery

33 For the philosophical meaning of Utopia, see Ernst Bloch, Geist der Utopie, München, 1918; I consulted the Italian translation: Lo spirito dell'utopia (ed. F. Coppellotti), Milan: BUR, 2009; while for the different etymologies, I suggest Lewis Mumford, The Story of Utopias (1922), Whitefish: Kessinger Publishing, 2003.

34 Walter Benjamin, The Origin of German Tragic Drama (1963), London - New York: Verso, 1998, p. 140. 


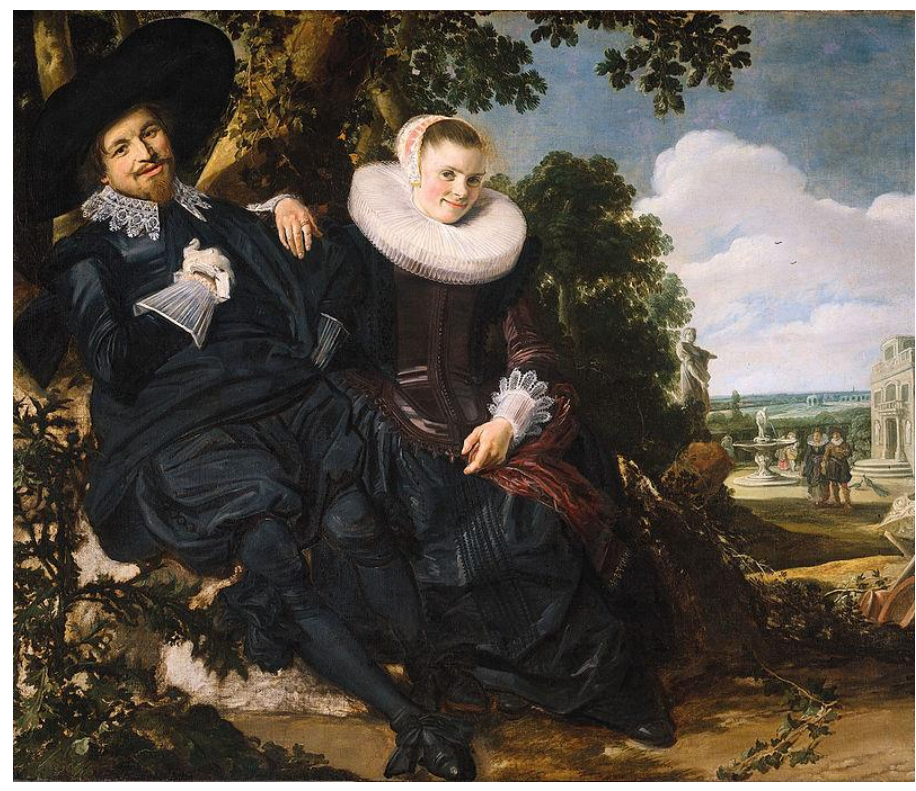

Fig. 2: Frans Hals, Marriage Portrait of Isaac Massa and Beatrix van der Laen, 1622, Amsterdam, Rijksmuseum.

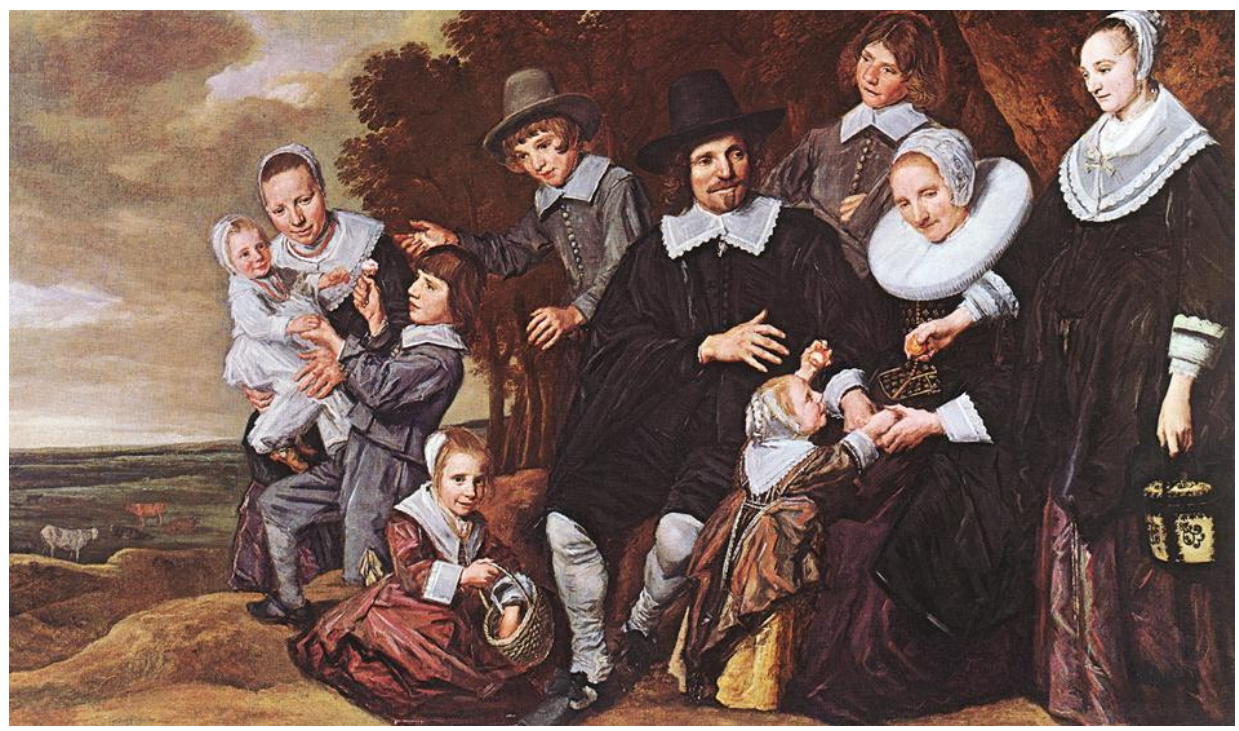

Fig. 3: Frans Hals, A Family Group in a Landscape, 1645-'47, London, National Gallery. 


\section{Bibliography}

Anselmi, Gian Mario, Elam, K., Forni, G., Monda, D. (eds.), Lirici europei del Cinquecento. Ripensando la poesia del Petrarca, Milan: BUR, 2004.

Benjamin, Walter, The Origin of German Tragic Drama (1963), London - New York: Verso, 1998.

Brugnolo, Furio, La lingua Di cui si vanta Amore. Scrittori stranieri in lingua italiana dal Medioevo al Novecento, Rome: Carocci, 2009.

Christopher, Joby, 'The Use of Greek in the Correspondence of Constantijn Huygens (1596-1687)', Humanistica Lovaniensia, 61 (2012), pp. 333-353.

Christiaan Huygens, Oeuvres complètes de Christiaan Huygens publiées par la Société Hollandaise des Sciènces, 22 vols, La Haye: Martinus Nijhoff, 1888-1950.

Constantijn Huygens, Gedichten. Deel 4: 1644-1652, ed. J.A. Worp, Groningen: J.B. Wolters, 1894.

Constantijn Huygens, Journaal van de reis naar Venetië, red. F.R.E. Blom, Amsterdam: Prometheus - Bert Bakker, 2003.

Constantijn Huygens, Mijn jeugd, ed. C.L. Heesakkers, Hilversum: Griffioen, 1987.

De Jager, Astrid, 'Constantijn Huygens' Passion: Some Thoughts About the «Pathodia SacraEt Profana», Tijdschrift Van De Koninklijke Vereniging Voor Nederlandse Muziekgeschiedenis, 57:1 (2007).

Folena, Gianfranco, L'italiano in Europa. Esperienze linguistiche del Settecento, Turin: Einaudi, 1983.

Forster, Leonard, The Poets Tongues. Multilingualism in Literature, Cambridge: Cambridge University Press, 1970.

Horace, Ars Poetica, in Id., Opere, Turin: UTET, 2008.

Joby, Christopher, The multilingualism of Constantijn Huygens (1596-1687), Amsterdam University Press, 2014. 
Levi, Carlo, Prima e dopo le parole. Scritti e discorsi sulla letteratura, Rome: Donzelli, 2001.

Rasch, Rudolf, “'Italia decolor”? Constantijn Huygens and Italian Music', in Dinko Fabris, Margaret Murata (eds.), 'Passaggio in Italia': Music on the Grand Tour in the Seventeenth Century, Turnhout: Brepols, 2015.

Lo Cascio, Vincenzo, 'L'italiano nel secolo d'oro olandese', in Harro Stammerjohann (ed.), Italiano: lingua di cultura europea, Atti del simposio internazionale in memoria di Gianfranco Folena, Weimar, 11-13 aprile 1996, Tübingen: Narr, 1997.

Pieters, Jürgen, Op zoek naar Huygens. Italiaanse leesnotities, Gent: Koninklijke Academie voor Taal- en Letterkunde, Poëziecentrum, 2014.

Teskey, Gordon, The Poetry of John Milton, Cambridge: Harvard University Press, 2015.

Verkuyl, Pieter E.L., 'Is Huygens een marinist?', De Nieuwe Taalgids, 56 (1963), pp. 129-140, pp. 193-205.

Vincent, Teskey, 'Review to Frits Noske, Pathodia sacra et profana by Constantijn Huygens', Journal of the American Musicological Society, 14:1 (Spring 1961), pp. 82-83.

Ypes, Catharina, Petrarca in de Nederlandse letterkunde, Amsterdam: De Spieghel, 1934. 